\title{
МЕТОДИЧНІ ПІДХОДИ ДО ОЦІНЮВАННЯ РИНКОВОГО ПОТЕНЦІАЛУ РЕГІОНУ
}

\author{
Тесля Дмитро Вадимович \\ аспірант \\ ДУ «Інститут регіональних досліджень ім. М.І. Долішнього НАН України» (м. Львів, Україна) \\ ORCID: 0000-0002-1746-3656 \\ teslyad@i.ua
}

У статті розкрито сутність поняття «ринковий потенціал регіону» та обгрунтовано його роль у вирішенні наукових та прикладних завдань. Охарактеризовано методичні підходи до оцінювання сукупності характеристик регіональних товарних ринків в розрізі декількох оціночних площин, зокрема: розміру (ємності та масштабу) ринку; його доступності $i$ ступеня насиченості товарами; рівня конкуренції, стабільності та конкурентоспроможності ринку; просторової нерівномірності розподілу виробничого і споживчого потенціалів. Зазначено, що при оцінці ринкового потенціалу регіону доцільно оцінювати також ступінь відкритості ринку, який характеризує вплив зовнішніх по відношенню до регіонів ринків. Запропоновано методику оцінки ринкового потенціалу регіону, яка включає поетапний алгоритм аналізу особливостей його формування та використання на основі оцінки його параметрів в розрізі структурного та просторового підходів. Відзначено, що алгоритм оцінки ринкового потенціалу регіону має комплексний характер оскільки базується на врахуванні чинників зовнішнього і внутрішнього середовища.

Ключові слова: ринковий потенціал регіону, ємність регіонального товарного ринку, привабливість ринку, масштаб і доступність ринку.

DOI: https://doi.org/10.32845/bsnau.2019.4.31

Постановка проблеми. Сучасний етап розвитку вітчизняної економіки пов'язують із формуванням внутрішнього ринку України, який є відображення структури та характеру особливостей функціонування національної економічної системи. Зростання цін на товари, паливно-мастильні матеріали, збільшення енергетичних витрат на виробництво, а також збільшення ціни на газ, зростання імпортозалежності і загального зменшення промислового виробництва в Україні зумовлюють наявність перешкод у функціонуванні внутрішнього ринку країни. В свою чергу проблеми і труднощі, що виникають на внутрішньому ринку товарів та послуг призводять до загострення економічних, соціальних, демографічних, політичних суперечностей у суспільстві і, відповідно, підривають фінансово-економічні основи розширеного відтворення та сталого економічного зростання. Крім того, невирішеність проблем на внутрішньому ринку призводять до посилення залежності національної економіки від кон'юнктури на світовому ринку. Крім того, внутрішній ринок $€$ визначальним механізмом регулювання та координації дій суб'єктів господарювання, а також місцем узгодження попиту і пропозиції на ринку товарів, послуг. Чинником успішного функціонування внутрішнього ринку країни та регіональних товарних ринків виступає ринковий потенціал, який формується з одного боку зусиллями різних суб'єктів господарювання, що виробляють товари та надають послуги, а з іншої сторони можливостями споживачів щодо купівлі певних товарів та отримання послуг.

За цих умов оцінка ринкового потенціалу регіонів виступає вкрай актуальною науковою проблемою, яка дозволить виявити проблеми розвитку регіональних товарних ринків та запропоновувати комплекс заходів з їх усунення.

Аналіз останніх досліджень і публікацій. Питання оцінювання ринкового потенціалу регіонів та його окремих складових лежить в площині розвитку теорії ринків в економічній науці, моделях нерівномірності розподілу економічної активності нової економічної географрії і регіональної економіки. Різні аспекти оцінки ринкового потенціалу на макро- мезо- та мікрорівнях висвітлені у працях П. Комба, Ф. Котлера, П. Кругмана, Ж.-Ж. Ламбена, Р. Люса Т. Майера, П. Рейлі, Дж. Харріса, Д. Хаффра, К. Хеда, Р. Холла, А. Чикконе, Ф. Феттера, Т.О. Зайчук, В.Я. Кардаша, Е. А. Коломака, В.П. Пилипчука, І.Є. Трубхіної, І.В. Філімоненко та інших.

Оцінювання ринкового потенціалу регіонів потребує комплексного підходу, який враховуватиме наявний потенціал ринку в розрізі виробничого, споживчого та інфраструктурного потенціалів, що свідчатимуть про рівень його привабливості і конкурентоспроможності.

Метою статті $€$ висвітлення особливостей існуючих методичних підходів до оцінювання характеристик регіональних товарних ринків та обґрунтування авторської методики комплексної оцінки ринкового потенціалу регіонів.

Виклад основного матеріалу. Ринковий потенціал регіону є комплексним поняттям, яке включає сукупність виробничого, споживчого та торгівельного потенціалів, взаємодія яких створює синергетичний ефект.

Важливим аспектом вивчення ринкового потенціалу підприємства є формування підходу до його кількісної оцінки. Виходячи з визначення сутності поняття «ринкового потенціалу» доходимо висновку, що його оцінювання за кількісними оцінювання за кількісними та якісними параметрами може бути використано для вирішення низки завдань:

- оцінки стану та тенденцій розвитку, привабливості та конкурентоспроможності регіонального товарного ринку;

- виявлення закономірностей просторового розміщення виробничих та торгівельних об'єктів (вибору місця їх розташування з позиції оцінки доступності об'єктів);

- оцінки ступеня просторової нерівномірності регіонального розвитку;

- аналізу просторового розподілу економічної активності в регіонах та ступеня її концентрації;

- оцінці зовнішньоторговельного потенціалу регіонів та визначення рівня інтенсивності міжрегіональних економічних зв'язків; 
- вибору інструментів державного регулювання розвитку регіональних товарних ринків.

В економічній науці існує низка підходів до оцінювання ринкового потенціалу як на макро-. мезо- та мікрорівні. 3окрема, Зайчук Т.О. вважає, що для здійснення комплексної оцінки привабливості окремих ринкових сегментів величину первинного попиту доцільно порівняти з абсолютним потенціалом ринку. Для оцінки ринкового потенціалу вчена пропонує розраховувати абсолютну величину загального ринкового потенціалу $(\mathrm{Q})$ за таким алгоритмом [1, с. 99]:

$$
Q=n \cdot p \cdot q \cdot v,
$$

де $Q$ - абсолютний ринковий потенціал; $n$ - кількість потенційних споживачів товару; $p$ - середня ціна одиниці товару; $q$ - частота купівлі товару; $v$ - максимальний обсяг споживання товару.

При цьому вчена наголошує, що абсолютний ринковий потенціал - це верхня межа попиту за певний період часу, розрахунок якої базується на припущенні, що всі потенційні споживачі будуть вибирати виключно конкретний товар і споживати його по максимуму. Це припущення є гіпотетичним, на практиці навіть за умови здійснення максимально можливих зусиль із забезпечення попиту, досягнення абсолютного ринкового потенціалу не є можливим, оскільки нереально досягти того, щоб товар використовували всі, хто так чи інакше здатний це зробити за кожної зручної можливості в максимально можливому обсязі [1, с. 98].

Такий підхід до розрахунку ринкового потенціалу не враховує виробничий і торговельний потенціал регіону, тобто можливості його підприємств реалізувати свою продукцію як на макро-, так і мезорівні, а також потенційну ємність ринку (обсяг продажу товарів споживачам), яка свідчатиме про перспективність ринку. І оскільки будь-який ринок формується під впливом багатьох фракторів (соціальних, технологічних, економічних, політичних тощо), кожен з них за певних обставин і в певний проміжок часу може як стимулювати, так і стримувати ринок.

До основних факторів формування та використання ринкового потенціалу належать: прогнозований рівень життя населення, динаміка його купівельної спроможності, динаміка заробітної плати, прогнозована чисельність населення та його статево-вікова структура, прогнозований рівень цін, перспективи розвитку торговельної мережі, географічне розташування ринку тощо [2, с. 236].

3 огляду на вищевказане, оцінювання ринкового потенціалу передбачає оцінку стану та тенденцій розвитку, рівнів привабливості та конкурентоспроможності регіонального товарного ринку, що насамперед, передбачає визначення ємності ринку, оцінку доступності ринку та ступеня насиченості ринку, а також аналіз конкуренції на ринку та його стабільності [3, с.89]. Останній може здійснюватися за показниками, які свідчать про рівень ринкової концентрації, монополізації та нерівномірності розподілу ринкових часток, рівня конкуренції та рівня відкритості ринку. Оцінка ємності ринку та ступеня насиченості його товарами свідчить про масштаб (розмір) ринку.

Аналіз привабливості будь-якого регіонального/локального ринку Ж. Ж. Ламбен і І.В. Філімоненко пропонують здійснювати на основі оцінки динаміки індексу купівельної спроможності (IКC) населення території. ІКС дозволяє визначити привабливість ринку, розташованого в межах певного регіону шляхом встановлення середнього значення трьох ключових компонент ринкового потенціалу [3; 4]: кількості споживачів, купівельної спроможності споживачів, готовності споживачів до відповідних витрат.

Запропонований вченими метод оцінки привабливості регіональних/локальних ринків дозволяє в залежності від рівня ІКС ранжувати території за обсягами споживчого потенціалу.

Крім того, І.В. Філімоненко пропонує методичні підходи до оцінки [3]: внутрішніх можливостей регіону щодо задоволення платоспроможного попиту на ринку споживчих товарів; конкурентних переваг споживчих товарів для формування та розвитку локальних ринків регіону, ефективності та перспективності окремих товарних груп, Окреслена сукупність методичних підходів дозволить проводити порівняльну оцінку ефективності виробництва окремих видів продукції промисловості, визначити споживчу спеціалізацію локальних та регіональних ринків, виробити стратегію розвитку локальних ринків.

При оцінці ринкового потенціалу регіону доцільно використовувати показники, які характеризують вплив зовнішніх по відношенню до регіонів ринків. До таких показників відносимо ті, які свідчать про обсяги зовнішньоекономічної діяльності та показник відкритості ринку. Ступінь відкритості ринку вказує на можливості входу на товарний ринок продавців 3 інших регіонів та особливості його взаємодії із зовнішнім та внутрішнім середовища,

Для оцінки відкритості регіонального ринку з позиції попиту Карліна Т.В. пропонує використовувати показник частки попиту на товар зовнішніх по відношенню до регіону споживачів у загальному попиті виробленого товару, а також того, що продається в регіоні. Для оцінки відкритості ринку 3 позиції пропозиції вчена пропонує розраховувати показник частки пропозиції з боку зовнішніх по відношенню до регіону виробників у загальній пропозиції товару, що включає виробництво товару в регіоні, а також зовнішні поставки товару в регіон [5, с. 17].

Аналіз відкритості ринку є важливим при обґрунтуванні вибору інструментів державного регулювання регіонального товарного ринку.

Важливою площиною оцінювання ринкового потенціалу регіону $є$ доступність ринку. Саме при виборі місця розташування виробничих та торгівельних об'єктів, які є складовими ринкового потенціалу регіону визначальну роль відповідно до сутності агломераційних моделей відіграє попит на продукцію фрірми, який оцінюється через доступність ринку. Агломераційний ефект на регіональному товарному ринку виникає за таких умов: виробники зосереджуються там, де попит $€$ найбільшим і $€$ можливість обслуговувати менші ринки шляхом експорту товарів (між національними ринками), або шляхом активізації міжрегіональних економічних зав'язків (в межах національного ринку). За цих умов зростає значення ціни транспортних витрат.

3 метою доведення наявності ефекту агломерації на ринку К. Хедом і Т. Майером було побудовано економетричну модель вибору місця розташування дочірніх філій фрірми «Toyota» для дев'яти європейських країн (Бельгія, Франція, Німеччина, Ірландія, Італія, Нідерланди, Іспанія, Португалія та Сполучене Королівство). У якості детермінантів вибору місця розташування вчені обрали такі показники: рівень заробітної плати, безробіття, кількість промислових 
підприємств, податок на прибуток підприємств, соціальні податки та торгівельні витрати. Отримані результати довели наявність стійкого впливу агломераційних ефектів [6].

При виборі місць розташування об'єктів роздрібної торгівлі діють гравітаційні ефекти. Їх сутність сформулював П. Рейлі в законі гравітації розрібної торгівлі, який стосується визначення меж ринкових зон двох конкуруючих міст - ринкових центрів. Згідно цього закону на ринковий потенціал конкуруючих міст впливає купівельна спроможність периферії. Гравітаційна модель роздрібної торгівлі П. Рейлі пояснює як місто виступаючи центром тяжіння торгівельних потоків прилеглої території з-силою пропорційною розміру міста і обернено пропорційною квадрату відстані від клієнта до центру міста. Згідно моделі Рейлі інтенсивність торгівлі між двома регіонами пропорційна відношенню їх ВВП і відстані між ними [7].

При оцінці місць розташування об'єктів торгівельної інфраструктури заслуговують на увагу методичні підходи, що використовують в сфрері просторового планування. Так Деміним Н.М. були досліджені закономірності формування зон обслуговування підприємствами торгівлі різних рівнів (міжрегіонального, регіонального, міжрайонного і районного). На основі експериментальних даних вченим побудовано криві, що описують особливості привабливості об'єктів торгові для населення 3 врахуванням відстані між сусідніми містами і центрами різних рівнів і підприємствами торгівлі. Побудовані криві характеризують інтенсивність потоків населення в залежності від відстані поїздки до торговельних центрів міст. Побудовані криві засвідчили, що за умов віддалення від міста відбувається скорочення як абсолютної чисельності населення, до доїжджає до торгівельних об'єктів, так їх кількості в розрахунку на одиницю території зони [8].

Слід відзначити, що сучасні реалії вносять суттєві корективи до традиційних методів вибору місця розташування роздрібних торговельних об'єктів. Вони залежать від не тільки типу населених пунктів, а й потреб споживачів щодо асортименту товарів.

Для вибору місця розташування торговельного підприємства використовують також методи вимірювання торгівельної зони. Існує низка моделей, які використовують для оцінки та вибору місця розташування торгівельної точки. Серед них:

- модель П. Рейлі, що базується на основі оцінки ринкової частки підприємства і дозволяє оцінити оборот, прибуток і привабливість торговельної точки [9];

- модель Р. Люса, яка зорієнтована на врахування корисності використання (конкурентних переваг) тої чи іншої торговельної точки (район проживання та соціально-демограффічні характеристики покупця, наявність автомобіля тощо). Ця модель використовується для прогнозування частки ринку різних товарів і послуг [10];

- модель мультиплікативної взаємодії Д. Хафффа, яка включає два параметра оцінки місця розташування торговельного місця - площа торговельної точки та її віддаленість від споживача [11].

Отже, на вибір місця розташування торговельного підприємства впливає аналіз зони доступності об'єкта, яку характеризують розмір (площа) торгівельної зони, яка визначається на основі оцінки потенційної кількості клієнтів та про- гнозу торговельного обороту об'єктів торговельної інфраструктури, а також критеріїв її привабливості для споживача в т.ч. доступності (віддаленості) торговельної точки від споживача. Окрім характеристики кількісних та якісних параметрів населення (кількість домогосподарств, середня заробітна плата), яке проживає в межах зони доступності має значення і конкурентне середовище, що характеризується кількістю та типом торгівельних об'єктів (конкурентів).

Наступна площина оцінки ринкового потенціалу регіонів пов'язана із оцінкою ступеня просторової нерівномірності регіонального розвитку та просторового розподілу економічної активності в регіонах. В цьому контексті йдеться про оцінку доступності ринку регіону до інших ринків. Саме такий підхід був застосований Дж. Харрісом, згідно якого ринковий потенціал визначається як зважена сума душових ВВП навколишніх регіонів з вагами, обернено пропорційними відстані між ними [12]:

$$
I P \Pi_{k}=\sum_{i=1}^{n}\left(\frac{1}{l_{i k}} q_{i}\right)
$$

де $k$ - номер регіону, для якого підраховується IPП, $n$ - кількість регіонів, $q_{i}$ - ВРП i-регіона, $l_{i k}$ - відстань між столицями $i$ - и k-регіонів.

При цьому враховуються особливості регіону: $1_{\mathrm{ii}}=2 / 3 \sqrt{\text { площчадь_региона/ } \pi}$.

Відповідно до задекларованого методичного підходу вищий індекс ринкового потенціалу свідчить про близькість більш економічно потужних регіонів, де сконцентровано більшу кількість виробників та споживачів і де спостерігається більша економічна активність. Цей методичний підхід для оцінки позиціювання ринку регіону враховує лише його транспорту доступність і не враховує обсяги міжрегіональних товарних потоків та експортний потенціал регіонів.

Вчені П. Комб та А. Чикконе, Р. Холл вказують, що близькість до великих ринків через наближеність до ринків ресурсів та економія на транспортних витратах підвищує їх ефективність. Вчені наголошують, що з іншого боку підвищення конкуренції сприяє пошуку більш ефективних виробничих та управлінських рішень [14; 15]

Отже, доволі часто для розрахунку ринкового потенціалу використовують показник обсягів виробництва регіону (ВРП), або ж суму ємності ринків, визначена на основі показника чисельності населення інших регіонів, поділену на відстань між ними. На нашу думку показник чисельності населення, його щільності і тим більше щільності зайнятих, рівень доходів, середня заробітна плата в регіоні свідчать про споживчий потенціал ринку та розмір ринку.

Доволі часто вчені при дослідженні особливостей формування ринкового потенціалу звертають увагу на оцінку ринкового потенціалу територій у внутрішньо регіональному просторі, таким чином досліджується ринковий потенціал локальних ринків. Так, І.Є. Трубехіна розвиває підхід Дж. Харріса і пропонує оцінювати ринковий потенціал регіону як внутрішньорегіональну характеристику, називаючи його центральним в рамках моделі центрально-периферійних відносин (між районами певного регіону та регіональним центром) [16].

Зазвичай для оцінки ємності ринку використовують 
обсяги виробництва сусідніх територій або ВРП, проте вчений пропонує використовувати показник чисельності населення, а ринковий потенціал регіону розраховує як суму ємності ринків інших регіонів поділених на відстані між ними.

Застосування цього методичного підходу дозволяє оцінити не тільки економічні зв'язки між районами та обласним центром, а також залежність економічної активності в містах і районах регіону від щільності населення. Розглянутий методичний підхід до оцінки внутрішньо регіонального ринкового потенціалу може бути використаний для оцінки центрально-периферійних відносин в межах регіонів.

Враховуючи існуючі методичні підходи до оцінювання ринкового потенціалу регіонів доходимо висновку, що алгоритм його оцінки має комплексний характер і базується на врахуванні чинників зовнішнього і внутрішнього середовища та використанні структурного та просторового підходів для оцінки його параметрів (рис. 1).

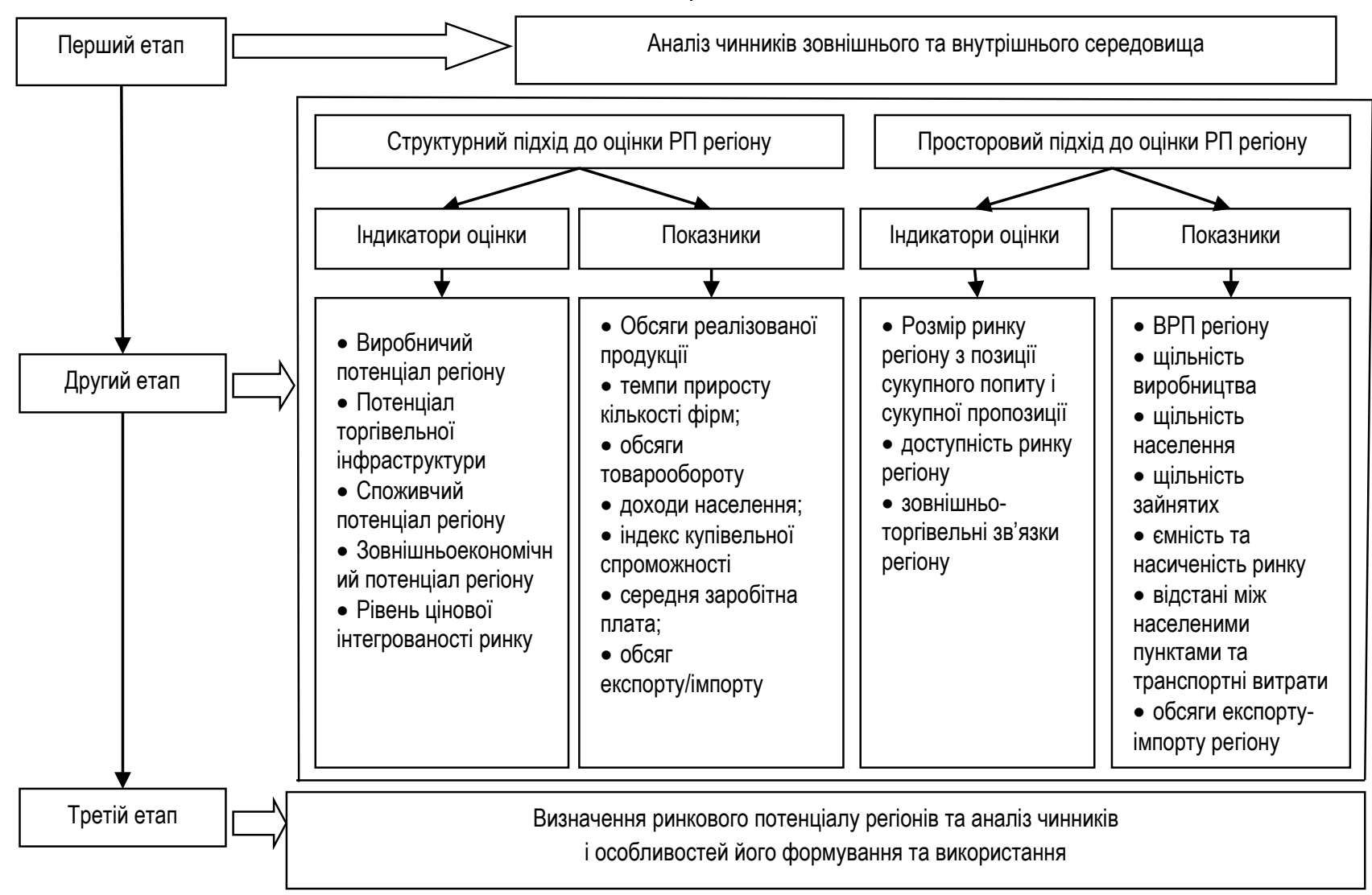

Рис. 1. Алгоритм аналізу та оцінки ринкового потенціалу регіону

Висновки. Підсумовуючи вищесказане доходимо висновку, що оцінювання ринкового потенціалу регіону може використовуватись для розв'язання низки дослідницьких чи прикладних завдань - від оцінки просторової нерівномірності розподілу економічного потенціалу територій до визначення пріоритетів регіональної економічної політики регіонів та розробки стратегій регіонального розвитку на середньо- та довгострокову перспективу.

\section{Список використаної літератури:}

1. Зайчук Т.О. Теоретичні аспекти визначення ринкового потенціалу і маргетингу вітчизняними підприємствами. Маркетинг і менеджмент інновацій. 2012. №1. С. 96-104.

2. Григорьев Д.А., Суслова Ю.Ю. Теоретические и методические подходы к изучению рыночного потенциала и его емкости, Проблемы современной экономики, 2014. №2 (50). С. 234-237.

3. Филимоненко И. В. Методика оценки и выбора эфффективных локальных рынков региона. URL:https://nsu.ru/rs/mw/link/Media:/22331/11_Filimonenko.pdf

4. Ламбен Ж. Ж. Менеджмент, ориентированный на рынок. Стратегический и операционный маркетинг. СПб.: Питер, 2004.

5. Карлина Т.В. Развитие механизма регулирования системы региональных товарных рынков на основе иерархического подхода. Автореферат диссертации на соискание ученой степени кандидата экономических наук: Специальность 08.00.05 - Экономика и управление народным хозяйством (региональная экономика), 2010. 23с.

6. Head K., Mayer T. Market potential and the location of japanese investment in the european UNION. URL: https://spire.sciencespo.fr/hdl:/2441/10192/resources/mayer-head-res-2004.pdf

7. Ray D. Market Potential and Economic Shadow: A Quantitative Analysis of Industrial Location in Southern Ontario. Chicago: University of Chicago $p$.

8. Domin, N.M. (1991). Upravleniye razvitiye gradostroitel'nykh sistem. 
9. Reilly W. J. The Law of Retail Gravitation. New York: Knickerbrocker Press, 1931.

10. Luce R. Individual Choice Behavior // New-York: John Wiley \& Sons, 1959.

11. Huff D.L. Defining and Estimating a Trade Area // Journal of Marketing. 1964. №28. P. 34-38.

12. Harris C. D. The market as a factor in the localization of production. Annals of the Association of American Geographers, 1954. P. 315

13. Combes P.-P., Mayer T., Thisse J.-F. Economic Geography. The Integration of Regions and Nations. Princeton, NJ, Princeton University Press, 2008.

14. Ciccone A., Hall R. E. Productivity and the Density of Economic Activity. American Economic Review, 2996, vol. 86 (1), P. 54-70.

15. Трубехина И.Е. Анализ механизмов пространственной концентрации (на примере малого бизнеса в Сибирском федеральном округе). Вестник Новосибирского государственного университета. Серия: Социально-экономические науки. 2014. Т. 14. вып. 2. С. 101-117.

\section{References:}

1. Zajchuk, T. O. (2012). Teoretychni aspekty vyznachennja rynkovogho potencialu i marghetynghu vitchyznjanymy pidpryjemstvamy [Theoretical aspects of determining market potential and marketing by domestic enterprises]. Marketyngh i menedzhment innovacij - Marketing and innovation management, 1, 96-104.

2. Grigor'yev, D.A., Suslova, Yu.Yu. (2014). Teoreticheskiye i metodicheskiye podkhody k izucheniyu rynochnogo potentsiala i yego yemkosti [Theoretical and methodological approaches to the study of market potential and its capacity] Problemy sovremennoy ekonomiki - Problems of the modern economy, 2(50), 234-237.

3. Filimonenko, I.V. (2006). Methodology for assessing and choosing effective local markets in the region [Methodology for assessing and choosing effective local markets in the region]. URL: https://nsu.ru/rs/mw/link/Media: /22331/11_Filimonenko.pdf

4. Lamben, Zh. Zh. (2004). Market-oriented management. Strategic and operational marketing [Menedzhment, oriyentirovannyy na rynok. Strategicheskiy i operatsionnyy marketing]. SPb.: Piter.

5. Karlina, T.V. (2010). Razvitiye mekhanizma regulirovaniya sistemy regional'nykh tovarnykh rynkov na osnove iyerarkhicheskogo podkhoda [Development of a mechanism for regulating the system of regional commodity markets based on a hierarchical approach]. Avtoreferat dissertatsii na soiskaniye uchenoy stepeni kandidata ekonomicheskikh nauk: Spetsial'nost' 08.00 .05 Ekonomika i upravleniye narodnym khozyaystvom (regional'naya ekonomika), 2010. 23s..

6. Head, K., Mayer., T. (2004). Market potential and the location of japanese investment in the european UNION. URL: https://spire.sciencespo.fr/hdl:/2441/10192/resources/mayer-head-res-2004.pdf

7. Ray, D. (1965). Market Potential and Economic Shadow: A Quantitative Analysis of Industrial Location in Southern Ontario. Chicago: University of Chicago.

8. Domin, N. M. (1991). Upravleniye razvitiye gradostroitel'nykh sistem [Management of the development of urban planning systems]. Kyev.

9. Reilly, W. J. (1931). The Law of Retail Gravitation. New York: Knickerbrocker Press.

10. Luce, R. (1959). Individual Choice Behavior // New-York: John Wiley \& Sons.

11. Huff, D.L. (1964). Defining and Estimating a Trade Area. Journal of Marketing, №28. R. 34-38.

12. Harris, C. D. (1954). The market as a factor in the localization of production. Annals of the Association of American Geographers.

13. Combes, P.-P., Mayer, T., Thisse, J.-F. (2008). Economic Geography. The Integration of Regions and Nations. Princeton, NJ, Princeton University Press.

14. Ciccone, A., Hall, R. E. (2013). Productivity and the Density of Economic Activity. American Economic Review, 2996, 86(1), 54-70.

15. Trubekhyna, Y.E. (2014). Analiz mekhanizmov prostranstvennoy kontsentratsii (na primere malogo biznesa v Sibirskom federal'nom okruge) [Analyz mekhanyzmov prostranstvennoj koncentracyy (na prymere malogho byznesa v Sybyrskom federaljnom okrughe]. Vestnik Novosibirskogo gosudarstvennogo universiteta. Seriya: Sotsial'no-ekonomicheskiye nauki - Novosibirsk State University Bulletin. Series: Socio-economic sciences, 14.2, 101-117.

Teslya Dmytro Vadymovych, Postgraduate of the Department of regional economic policy of the SI "Institute of Regional Research n.a. M.I. Dolishniy of the NAS of Ukraine", Lecturer of the Lviv State College of Food and Processing Industry of the National University of Food Technologies (Lviv, Ukraine)

Methodological approaches to the evaluation of a region's market capacity

The paper outlines the nature of the concept "a region's market capacity" and substantiates its role in the solution of scientific and practical tasks. It characterizes the methodological approaches to evaluation of a set of features of regional goods markets across several evaluation areas, including the market size (capacity and scale); its accessibility and level of goods saturation; level of market competition, stability, and competitiveness; spatial inequality of the distribution of production and consumption capacity. Special attention is paid to the analysis of existing methodologies of local markets' attractiveness evaluation that are based on the evaluation of the consumer capacity in the context of revealing the internal capacity of a region to meet the effective demand. The fact that it is reasonable to evaluate the level of the market's openness that characterizes the impact of markets external to the regions in the course of evaluating the region's market capacity is emphasized. The impact of agglomeration on the selection of the location of production and sales facilities that are the components of the region's market capacity is substantiated. The main determinants of the choice are 
defined and characterized. Methodological approaches to evaluation of a territory's market capacity in intraregional space - local markets - are researched. The approach is proven to be efficient for evaluation of center-periphery relations within regions, i.e. it allows evaluating not only economic links between districts and oblast centers but also detecting the dependence of economic activity in cities and districts of the region on the density of population and density of employed. The paper suggests the methodology of evaluation of a region's market capacity that includes the stage-by-stage algorithm of analysis of its forming and use features based on evaluation of its parameters across structural and spatial approaches. The fact that the algorithm of evaluation of a region's market capacity is of complex nature due to accounting the factors of external and internal environments is emphasized. market.

Key words: region's market capacity, capacity of regional goods market, market attractiveness, scale and accessibility of the

Дата надходження до редакції: 20.11.2019 р. 